8 - ORIGINAL ARTICLE

EXPERIMENTAL SURGICAL INFECTIONS

\title{
Copaiba oil effect under different pathways in mice subjected to sepsis ${ }^{1}$
}

\author{
Nara Macedo BotelhoI, Edvaldo Lima Silveira" ${ }^{\mathrm{II}}$, Letícia Nobre Lopes ${ }^{\mathrm{III}}$, Felipe Augusto Folha Santos ${ }^{\mathrm{IV}}$, Renan Kleber Costa \\ Teixeira $^{\mathrm{V}}$, Thaís Travassos da Silva ${ }^{\mathrm{VI}}$
}

DOI: http://dx.doi.org/10.1590/S0102-86502014000800008

IPhD, Full Professor, Head, Department of Integrate Health, Medical School, University State of Para (UEPA), Brazil. Conception and design of the study, manuscript writing, critical and final revision.

IIFellow PhD degree, Postgraduate Program in Infectious and Parasitic Diseases, UFPA, Belem-PA, Brazil. Histological examinations, critical revision.

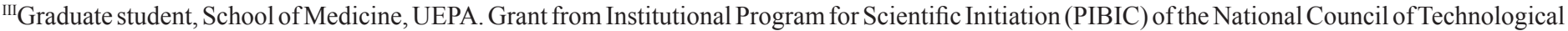
and Scientific Development (CNPq), Ministry of Science, Technology and Inovation, Brazil. Technical procedures, manuscript preparation.

${ }^{\mathrm{IV}}$ Graduate student, School of Medicine, UEPA. PIBIC, CNPq, Brazil. Technical procedures, statistical analysis, interpretation of data, manuscript preparation.

${ }^{\mathrm{V}}$ Graduate student, School of Medicine, UEPA. PIBIC, CNPq, Brazil. Care of animals, statistical analysis, manuscript preparation.

${ }^{\mathrm{VI}}$ Graduate student, School of Medicine, UEPA. PIBIC, CNPq, Brazil. Care of animals, technical procedures, manuscript preparation.

\section{ABSTRACT}

PURPOSE: To evaluate the effects of copaiba oil administered by different routes on survival of mices subjected to cecal ligation and puncture.

METHODS: Thirty two mice were distributed into four study groups $(\mathrm{N}=8)$ : Sham group: normal standard animals; Control group: submitted a cecal ligation and puncture (CLP); Gavage group: submitted a CLP, and treat with copaiba oil by gavage; and Subcutaneous group: submitted a CLP, and treat with copaiba oil by subcutaneous injection. After the death of the histological analysis were performed. The Kaplan-Meier curves of surviving time were realized.

RESULTS: All animals that received copaiba, regardless of the route used, survived longer when compared to the control group $(\mathrm{p}<0.0001)$, whereas the survival time ranged from 20 hours for the control group up to 32 hours for the animals of gavage group and 52 for subcutaneous group. The animals that received gavage copaiba lived about and about 20 hours unless the subcutaneous group $(\mathrm{p}=0.0042)$. There was no statistical difference when compared the intensity of inflammatory response $(\mathrm{p}>0.05)$

CONCLUSION: Prophylactic subcutaneous administration of copaiba in mice subjected to severe sepsis by cecal ligation and puncture, resulted in a survival time higher than non-use or use of this oil by gavage.

Key words: Balsams. Peritoneal Diseases. Ligation. Mice. 


\section{Introduction}

Sepsis is the leading cause of death in intensive care units (ICU) with a mortality rateranging from 20 to $80 \%$, being diagnosed 18 million new cases of severe sepsis per year worldwide ${ }^{1-4}$.

The incidence of severe sepsis increased $91.3 \%$ over the past 10 years occurring in 1 to 3 per 1000 individuals in different regions, with annual growth of $1 \%$ per year ${ }^{1,5}$, representing still a severe public health problem in the world, both from the point of view of social and economic terms ${ }^{6}$. Brazil is appointed, along with the United Kingdon, as one of the countries with the highest rate of occurrence of sepsis in ICU, responsible for occupying about one quarter of the ICU beds ${ }^{3}$.

The treatment of sepsis represents a challenge for medicine ${ }^{7}$, because it still remains an entity of difficult clinical management. Possible interventions in the inflammatory response and coagulation with the goal of reducing morbidity and mortality, and improve the prognosis of sepsis, has been extensively investigated ${ }^{8}$.

The use of plants for medicinal purposes, for treatment, prevention and cure of diseases, is one of the oldest forms of medical practice of mankind. In the early 1990s, the World Health Organization reported that $65-80 \%$ of the population in developing countries depended on medicinal plants as the only form of access to basic health care ${ }^{9}$, and in relation to world population, about $60 \%$ makes use of medicinal plants ${ }^{10}$.

In Brazil, many species are still used empirically, without scientific support for efficacy and safety, which shows that, in a country with enormous biodiversity, there is a huge gap between the supply of plants and little research ${ }^{11}$.

One of the main medicinal plants used in the Amazon region, and the subject of many scientific studies is the copaiba oils, whose effects were tested and found effective in various activities, such as anti-inflammatory and antimicrobial ${ }^{12}$, especially against gram-positive bacteria ${ }^{13}$.

It is, therefore, a potential source of new agents against major infectious diseases ${ }^{13}$ having already reports in the literature about its benefits in sepsis induced in mice ${ }^{14}$. Still, the oil released by copaiba tree resin is low cost and easy access ${ }^{15}$ present in pharmacies throughout Brazilin various presentations ${ }^{16}$. Thus, the aim of this study is to evaluate the effects of copaiba oil administered by different routes on survival of mices subjected to cecal ligation and puncture.

\section{Methods}

Research approved by the Ethics Committee in the Use of Animals of the State University of Para (UEPA), protocol 17/13.

Thirty two adults males mice (Mus musculus) were used, weighing between 25 - 30grams, provided from the Animal Colony of the Experimental Surgery Laboratory of UEPA, kept in a controlled environment, with food and water ad libitum. The animals were randomized distributed into four groups, with eight animals each:

-Sham Group (SG): The animals were used as normal standard for survival and histological analysis;

-Control Group (CG): Animals were only realized the cecal ligation and puncture (CLP);

-Gavage Group (GG): Animals were realized the cecal ligation and puncture and treat with copaiba oil by gavage;

-Subcutaneous Group (SG): Animals were realized the cecal ligation and puncture and treat with copaiba oil by subcutaneous injection.

The animals were anesthetized with ketamine hydrochloride $(100 \mathrm{mg} / \mathrm{Kg})$ and xylazine hydrochloride $(10 \mathrm{mg} /$ $\mathrm{Kg}$ ), intraperitoneally. After was performed the epilation and antisepsis of the abdominal region. Subsequently, was performed a laparotomy of one centimeter.

After opening the abdominal cavity, the cecum was located, exposed and isolated, leaving the rest of the small and large intestine into the peritoneal cavity, taking care not to violate or damage the mesenteriais' vessels. The cecal ligation and puncture as realized by a $75 \%$ cecum ligated with silk 4-0 immediately after the ileocecal valve, to induce a high-grade sepis. After this, the cecal stump was transfixed by a single through-and-through puncture with a $21 \mathrm{G}$ needle. After the surgical procedure, was administered pre-heated saline $(5 \mathrm{ml}$ per100 g) by subcutaneously.

The gavage and subcutaneous group was tread by copaiba oil (Copaifera officinalis) $0,63 \mathrm{ml} / \mathrm{Kg}$ once, for five days before the cecal ligation and puncture, differentiating according to the administration route.

Confirmed the death of the animal was collect the lung of the animal, that were stored in $10 \%$ buffered formaldehyde and used for histopathological analysis by means of hematoxylin and eosin. It was analyzed in the lung the presence of necrosis, vascular congestion, and alveolar hemorrhage. It were analyzed by a semi-quantitative scale: 0 - absent, 1 - mild, 2 - moderate, 3 - severe.

Kruskall-Wallis and Fisher's exact test was used to compare the histopathological results. Survival curves of groups were plotted using the Kaplan-Meier method and then compared by the log-rank test. Was adopted a significance level of $5 \%$ to reject the null hypothesis. 


\section{Results}

No animals died in the Sham group, presenting good surgical recovery, and euthanized 30 days after the death of the animals in the other groups.

All animals that received copaiba, regardless of the route used, survived longer when compared to the control group $(\mathrm{p}<0.0001)$, whereas the survival time (Figure 1) ranged from 20 hours for the control group up to 52 hours for the animals of group Subcutaneous, corresponding to a survival time of 2.6 times greater $(\mathrm{p}=0.0003)$. The animals that received gavage copaiba lived about 12 hours more than the control $(\mathrm{p}=0.0017)$ and about 20 hours unless the subcutaneous group $(\mathrm{p}=0.0042)$.

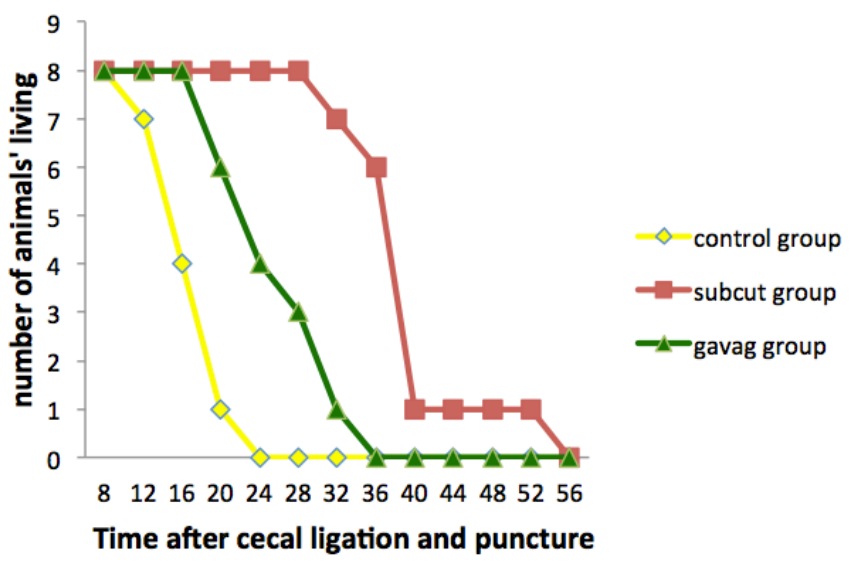

FIGURA 1 - Graph showing the survival curve of animals after performing cecal ligation and puncture, according to the group.

As regards the histopathological (Table 1) there was no statistical difference when compared the intensity of inflammatory response $(\mathrm{p}>0.05)$, having all groups displayed similar pattern of lung inflammatory response, with the presence of diffuse polymorphonuclear interstitial infiltration, vascular congestion, emphysema and focal areas of interstitial hemorrhage. However, it was observed the presence of tissue necrosis in $62.5 \%$ of the control group animals and none of the animals of the other groups $(\mathrm{p}=0.02)$.

\section{Discussion}

The present study demonstrated that there is significant difference in the organic response to severe sepsis when using different routes for the administration of copaiba oil. This maybe related to the longer time required for drug absorption according to the specific route, thus delaying the on set of it, which is a critical factor to the prognosis and survival of animals with sepsis.

Furthermore, the bioavailability of active molecules with antimicrobial and anti-inflammatory present in copaiba oil may be changed due to the mechanism of the first passage through the liver when administered by gavage. Thus, using the same dose for both routes (subcutaneous and gavage) probably resulted in increased action of the copaiba in subcutaneous group, culminating in the increased animal survival on this group.

Copaiba oil has been used by several authors to test its anti-inflammatory and antimicrobial effects ${ }^{17-19}$, and the results have shown that the main active components responsible for these properties are the diterpenes and sesquiterpenes, as bisabolol and beta betacariofileno9. Knowing that the copaiba used in this study does not show effects against gram-negative bacteria $^{13}$ and that the model of CLP primarily deflagrates gramnegative septicemia, it is believed that the determining factor for increasing animal survival was the anti-inflammatory action of this plant, by modulating the inflammatory response and subsequent issue damage mediated by free radicals and proinflammatory citocinais against sepsis.

When analyzed histologically in the lungs of mice, was observed that the use of copaiba oil was crucial to the progression of pulmonary status, been observed pattern of focal pulmonary necrosis only in animals that don't received the oil. This finding suggests appropriate systemic anti-inflammatory action of copaiba, in agreement with that described by Veiga Junior et al. ${ }^{20}$, which showed a decrease in the number of lung neutrophils and leukocytes, besides inhibiting the production of nitric oxide.

TABLE 1 - Main histopathological features according the group.

\begin{tabular}{cccccc}
\hline Group & $\begin{array}{c}\text { Interstitial infil- } \\
\text { trate }\end{array}$ & Emphysema & $\begin{array}{c}\text { Vascular } \\
\text { congestion }\end{array}$ & $\begin{array}{c}\text { Alveolar } \\
\text { hemorrhage }\end{array}$ & Necrosis \\
\hline & & & & & \\
Control & $2.00 \pm 0.93$ & $1.75 \pm 0.71$ & $2.50 \pm 1.07$ & $0.62 \pm 0.52$ & $0.75 \pm 0.71$ \\
Subcutaneous & $1.71 \pm 0.49$ & $1.86 \pm 0.69$ & $3.00 \pm 0.00$ & $0.71 \pm 0.76$ & $0.00 \pm 0.00$ \\
Gavage & $2.00 \pm 0.58$ & $2.00 \pm 0.58$ & $3.00 \pm 0.00$ & $0.43 \pm 0.53$ & $0.00 \pm 0.00$ \\
\hline
\end{tabular}

Source: Protocol search $\mathrm{p}>0.05$ (Kruskall-Wallis) 
Regardless of theroute used, the prophylactic use of copaiba oil for five days was effective to delay and mitigate the evolution of sepsis, and, judging by its wide use in Brazilian culture, especially Amazon, shows itself as an important component to be further studied for evidence of its role in popular usage.

\section{Conclusion}

Prophylactic subcutaneous administration of copaiba (copaifera reticulada) in mice subjected to severe sepsis by cecal ligation and puncture, resulted in a survival time of 2.6 and 1.5 times higher compared to non-use or use of this oil by gavage, respectively.

\section{References}

1. Silva E. Surviving sepsis campaign: um esforço mundial para mudar a trajetória da sepse grave. Rev Bras Ter Intensiva. 2006 Dec;18(4):325-7. doi: 10.1590/S0103-507X2006000400001.

2. Garrido AG, Figueiredo FLP, Silva MR. Experimental models of sepsis and septic shock: an overview. Acta Cir Bras. 2004 Apr;19(2):82-8. doi: 10.1590/S0102-86502004000200001.

3. Silva E. Sepse, um problema do tamanho do Brasil. Rev Bras Ter Intensiva. $2006 \mathrm{Jan} ; 18(1)$ : 5-6.

4. Friedman G, Silva E, Vincent JL. Has the mortality of septic shock changed with time? Crit Care Med. 1998 Dec;26:2078-86. PMID: 9875924.

5. Koenig A, Picon, PD, Feijó J, Silva E, Westphal GA. Estimate of the economic impact of implementing an in hospital protocol for the early detection and treatment of severe sepsis in public and private hospitals in southern Brazil. Rev Bras Ter Intensiva. 2010 Sep;22(3):213-9. doi: 10.1590/S0103-507X2010000300001.

6. Carvalho PRA, Trotta EA. Avanços no diagnóstico e tratamento da sepse. J Pediatr. 2003 Nov;79(2):195-204. doi: 10.1590/S002175572003000800009 .

7. Freitas JCO, Medeiros AC, Sales VSF. Proteção pela glucana em modelo experimental de sepse. Acta Cir Bras. 2004 Mai;19(3).296307. doi: 10.1590/S0102-86502004000300012.

8. Siqueira-Batista R, Gomes AP, Calixto-Lima L, Vitorino RR, Perez MCA, Mendonça EG, Oliveira MGA, Geller M. Sepse: atualidades e perspectivas. Rev Bras Ter Intensiva. 2011 Abril;23(2):207-16. doi: 10.1590/S0103-507X2011000200014.

9. Veiga junior VF, Maciel MAM. Plantas medicinais: cura segura? Quim Nova. 2005 Jun;28(3): 519-28.

10. Botelho NM, Corrêa SC, Lobato RC, Teixeira RKC, Quaresma JAS. Immunohistochemistry of the uterine cervix of rats bearing the Walker 256 tumor treated with copaiba balsam. Acta Cir Bras. 2013 Mar;28(3):185-9. doi: 10.1590/S0102-86502013000300005.

11. Foglio MA, Queiroga CL, Sousa IMO, Rodrigues RAF. Plantas medicinais como fonte de recursos terapêuticos: um modelo multidisciplinar. MultiCiencia. 2006 Out;7:1-8.

12. Pieri FA, Mussi MC, Moreira MAS. Óleo de copaíba (Copaifera sp.): histórico, extração, aplicações industriais e propriedades medicinais. Rev Bras Plant Med. 2009 Dec;11(4):465-72. doi: 10.1590/S1516-05722009000400016.
13. Santos AO, Ueda-Nakamura T, Dias FBP, Veiga JVF, Pinto AC, Nakamura CV. Antimicrobial activity of Brazilian copaiba oils obtained from different species of the Copaifera genus. Mem Inst Oswaldo Cruz. 2008 Jan;103(3):277-81. doi: 10.1590/S007402762008005000015.

14. Leal RA, Fontelles MJP, Rodrigues neto TS. Copaiba oil effects on survival rate after cecal ligation and puncture in mices. Rev Para Med. 2009 Jan;23(1):33-7.

15. Francisco SG. Uso do óleo resina de copaíba (Copaifera officinalis) em inflamação ginecológica. Femina. 2005 Fev; 33(2): 201-8.

16. Sachetti CG, Fascineli ML, Sampaio JA, Lameira OA, Caldas ED. Avaliação da toxicidade aguda e potencial neurotóxico do óleo resina de copaíba (Copaifera reticulate Ducke, Fabaceae). Rev Bras Farmacogn. 2009 Out;19(4):937-41.

17. Estevão LRM, Medeiros JP, Baratella-Evêncio L, Simões RS, Mendonça FS, Evêncio-Neto J. Effects of the topical administration of copaiba oil ointment (Copaifera langsdorffi) in skin flaps viability of rats. Acta Cir Bras. 2013 Dec;28(12):863-9. doi: 10.1590/S010286502013001200009.

18. Teixeira RKC, Yamaki VN, Yasojima EY, Brito, MVH. Effect of copaiba oil in hepatic damage induced by acetaminophen in rats. Acta Cir Bras. 2013 Jul;28(7):526-30. doi: 10.1590/S010286502013000700008 .

19. Yasojima EY, Teixeira RKC, Houat AP, Costa FLS, Silveira EL, Brito MVH, Lopes Filho GJ. Effect of copaiba oil on correction of abdominal wall defect treated with the use of polypropylene/ polyglecaprone mesh. Acta Cir Bras. 2013 Fev;28(2):131-5. doi: 10.1590/S0102-86502013000200008.

20. Veiga Junior VF, Rosas EC, Carvalho MV, Henriques MG, Pinto AC. Chemical composition and anti-inflammatory activity of copaiba oils from Copaifera cearensis Huber ex Ducke, Copaifera reticulate Ducke and Copaifera multijuga Hayne - A comparative study. J Ethnopharmacol. 2007 Jun;112(2):248-54. doi: 10.1016/j. jep.2007.03.005.

\section{Correspondence:}

Nara Macedo Botelho

Travessa Padre Eutíquio, 2264

66033-000 Belém - PA Brasil

Tels.: (55 91)3223-3609 / 8854-8896

narambotelho@gmail.com

Received: Mar 10, 2014

Review: May 12, 2014

Accepted: Jun 11, 2014

Conflict of interest: none

Financial sources: Institutional Program for Scientific Initiation (PIBIC), National Council for Technological and Scientific Development (CNPq), Ministry of Science, Brazil

${ }^{1}$ Research performed at Experimental Surgery Laboratory. School of Medicine, State University of Para (UEPA), Belem-PA, Brazil. Tutor: Nara Macedo Botelho. 